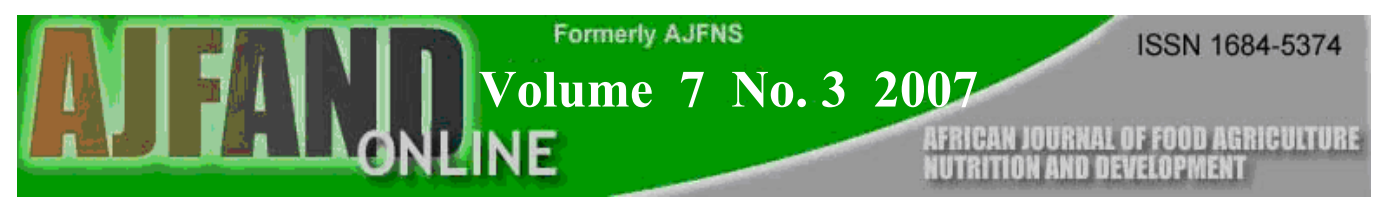

\title{
THE DIVERSITY OF CULTIVATED AFRICAN LEAFY VEGETABLES IN THREE COMMUNITIES IN WESTERN KENYA
}

Abukutsa-Onyango Mary ${ }^{1^{*}}$

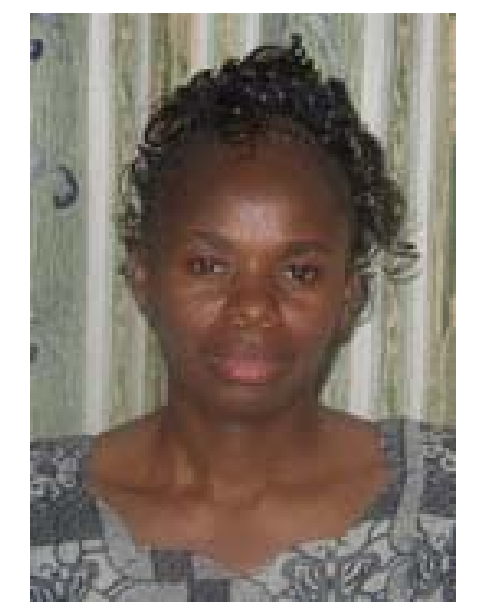

Prof. Mary Abukutsa Onyango

\footnotetext{
${ }^{1}$ Department of Botany \& Horticulture, Maseno University, Kisumu-Busia Road. P.O Box 333, 40105-Maseno, KENYA mabukutsa@yahoo.com
} 


\section{ABSTRACT}

High poverty levels in western Kenya that are manifested in malnutrition and poor health prevail yet the region is endowed with high agricultural biodiversity like African Leafy Vegetables (ALVs). The vegetables have high micronutrient content, medicinal properties, several agronomic advantages and economic value yet their potential in alleviating poverty and ensuring household food and nutrition security in the rural areas has not been exploited.

Despite all the above advantages, these vegetables have been neglected and face several constraints hampering optimal production such that if the situation is left unchecked it may result in loss of this biodiversity. It is because of this that a study was conducted with the objectives of documenting the diversity of African Leafy Vegetables and to collect indigenous knowledge on production, agronomic and cultural practices in three communities of Western Kenya. A survey was conducted between January 2002 and March, 2003, in six districts in Western and Nyanza provinces representing the Luhya, Luo and Kisii communities.

A structured questionnaire was administered to eighty purposively sampled respondents distributed in the ratio of 30:20:30 for Luhya, Luo and Kisii communities respectively. One focus group discussions per community was held and two key informants per community were interviewed. Over $90 \%$ of the respondents indicated that there was an increase in the cultivation of African Leafy Vegetables. Ten African Leafy Vegetables were found in the three communities representing eight botanic families. All the communities cultivated the ALVs at a subsistence level in home gardens, with organic sources of manure and under an intercrop system. Broadcasting was practiced by $20 \%, 40 \%$ and $60 \%$ of the respondents from the Luhya, Luo and Kisii communities respectively.

Harvesting was done by first uprooting at thinning then ratooning. The major constraints facing production of African Leafy Vegetables included lack of quality seed, pests and diseases, drought, poor marketing strategies and lack of technical packages. In conclusion, the study showed that all the three communities studied had a high diversity of cultivated African Leafy Vegetables covering eight botanic families; respondents in all the communities cultivate African leafy vegetable in a subsistence, home gardening, intercrop system where the use of chemical fertilizers and chemicals was minimal and the major constraints of production of African Leafy Vegetables included, poor quality seed, drought and poor marketing systems and infrastructure. The identified species should be promoted and improved as commercial crops.

KEY WORDS: Diversity, cultivation, African, Leafy, Vegetables

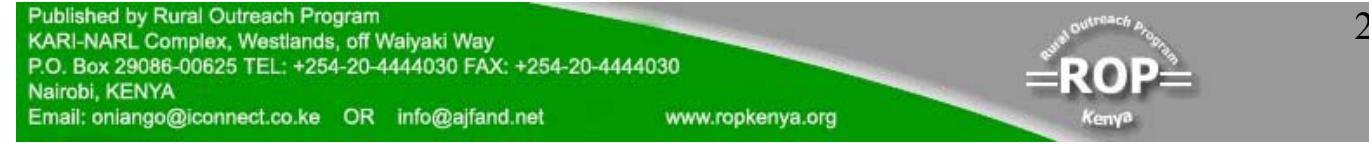




\section{INTRODUCTION}

Over $50 \%$ of people in rural communities in western Kenya have been reported to be living below the poverty line, thus living on less than one dollar a day [1]. Poverty normally manifests mainly in malnutrition and poor health which can be can be ameliorated by consumption of African Leafy Vegetables [2] The poverty situation has been worsened by the prevalence of HIV/AIDs and data from National HIV/AIDs Control Council of 2004 indicate that 2.5 million Kenyans are infected with about 200,000 new infections per year and yet the region is endowed with Agricultural biodiversity that include African Leafy Vegetables [3, 4]. These vegetables could contribute significantly in the management of the HIV/AIDS infected and affected persons.

African Leafy Vegetables (ALVs) are African indigenous or traditional vegetables whose leaves, young shoots and flowers are consumed $[5,6]$. These vegetables have been used by communities in Western Kenya for a long time [7]. There has been a renewed interest in African Leafy Vegetables by the policy makers and the international community on the realization that these vegetables have a potential that has yet to be exploited [8]. There is empirical evidence that African Leafy Vegetables have several advantages and values that include high micronutrient content, medicinal properties, several agronomic advantages and contribute to food and nutrition security and income generation $[9,10]$.

African Leafy Vegetables contain high levels of vitamin A, vitamin C, iron, calcium and protein and are a valuable source of nutrition in rural areas where they contribute substantially to protein, mineral and vitamin intake [11]. They are compatible to use with starchy staples and represent affordable nutrition to the poor sector in the population. Fresh leaves of most ALVs like vegetable amaranths, slenderleaf, spiderplant, vegetable cowpeas, pumpkin leaves and jute mallow contain more than $100 \%$ of the recommended daily allowances for vitamins and minerals and $40 \%$ proteins for growing children and lactating mothers $[12,13]$.

Many African Leafy Vegetables especially the sour or bitter ones like spiderplant, slenderleaf and African nightshades have been reported to heal stomach related ailments [9, 14]. Agronomic advantages of African Leafy Vegetables include: short growth period, where some of these vegetables are ready for harvest within 3-4 weeks; the ability to produce seed under tropical conditions; respond well to organic fertilizers and can tolerate both biotic and abiotic stress [6, 15]. Market survey conducted in Kakamega municipal market showed that African Leafy Vegetables constituted $20 \%$ in value for the traded produce during the period of study [16]. Socio-economic surveys conducted in various parts of Africa indicate that African Leafy Vegetables are important commodities in household food and nutrition security [10].

Women are known to be actively involved in the cultivation, processing and marketing of African Leafy Vegetables. A market survey conducted in 2001 in two rural and one municipal markets in western Kenya, women constituted 95 and $70 \%$ of

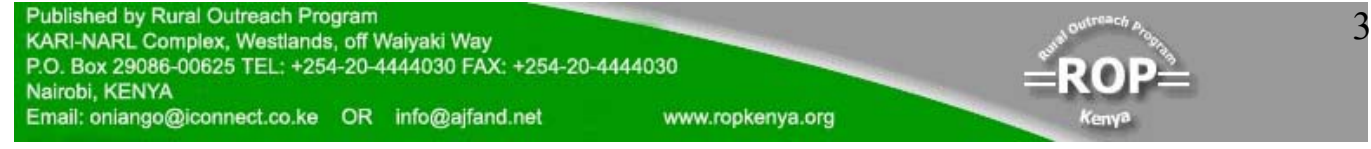


the respondents in the rural and municipal markets, respectively [16]. Despite the many advantages, African Leafy Vegetables have been neglected for a long time to the extent that some have become extinct and if this trend goes unchecked, there is a possibility that all could be lost. Promoting the production and utilization will ensure conservation by utilization, in which case if there is consumer demand of ALVs then production will be sustained to meet the demand and therefore avoid the threat to their extinction.

African Leafy Vegetables have not been fully exploited for food, nutrition and economic security in an endevour to alleviate poverty in Kenya and the Lake Victoria region. Some of the major constraints of production of African Leafy Vegetables include, poor quality seed, lack of production and utilization packages and poor marketing and processing strategies. African Leafy Vegetables normally face stiff competition with exotic vegetables like cabbage, spinach, exotic kale and lettuce among others [17].

The cultivation of African Leafy Vegetables in many western Kenya communities has always been done at a subsistence level and their potential as commercial commodities has not been exploited [4, 18]. To address some of the Millennium Development Goals that pertain to poverty, health, food and nutrition security for the African continent, interventions must include the neglected African indigenous plants have to be employed. Improving the quality and production of African Leafy Vegetables could be one of the powerful strategies to alleviate hunger, malnutrition and poor health in the region. It is, therefore, paramount to know the diversity of African Leafy Vegetables in the region and collect indigenous knowledge that could be useful in developing agronomic and utilization packages for improved production and utilization.

\section{OBJECTIVES}

Document the diversity of African Leafy Vegetables in three communities in western Kenya.

+ Collect indigenous knowledge on production, agronomic and cultural practices of African Leafy Vegetables in three communities of western Kenya.

\section{MATERIALS AND METHODS}

The study was conducted between January 2002 and March 2003, in six districts of two provinces that represent three communities in western Kenya. The choice of study sites was on the basis that these communities have cultivated and consumed African Leafy Vegetables for long yet they have not fully exploited the potential as an economic venture, yet people from these sites live in abject poverty The six districts included Vihiga and Butere/Mumias districts in Western Province representing the Luhya community, Kisumu and Siaya Districts in Nyanza Province representing the Luo community and Kisii and Nyamira Districts also in Nyanza province representing the Kisii Community.

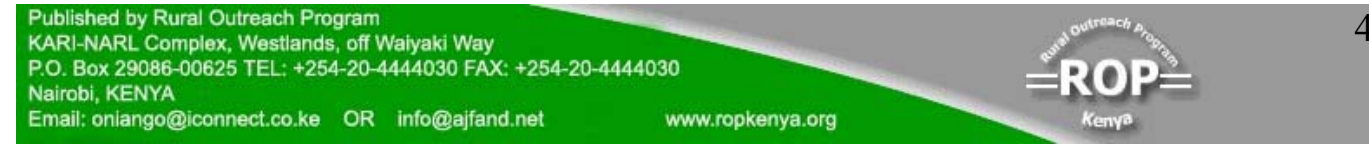


From these districts respondents were purposively sampled on the basis of their growing the African Leafy Vegetables. Eighty (80) structured questionnaires were administered to respondents in the various communities as follows: Luhya community 30 respondents, Luo community 20 respondents and Kisii community 30 respondents. Questionnaires were administered by research Assistants that were able to speak the local languages.

The Research assistants actually translated the questions into appropriate languages as they administered the questionnaire. In addition, one Focus Group Discussion (FGDs) was held in each community and a discussion with two key informants per community from the two districts for each community. Key informants included agricultural extension officers and local community leaders.

Information captured in the questionnaire included crops grown and the percentage land allocated to African Leafy Vegetables, the list of African Leafy Vegetables cultivated by the respondents, the agronomic practices, farming system and location of the farm, any African Leafy Vegetables they ate in the past and is no longer available, the preferred African Leafy Vegetable and the major constraints in the production of African Leafy Vegetables. The Focus Group Discussions and key informants were used to reconfirm what was indicated in the structured questionnaires.

Data collected from the study were analyzed by both qualitative and quantitative methods. The quantitative approach was used to discuss data from focused group discussions and key informants. Descriptive statistics was used to explain the quantitative part where percentages of the various responses were used and presented in form of tables.

\section{RESULTS}

\section{Diversity of African Leafy Vegetables in three commmuties in western Kenya}

Tables 1, 2 and 3 show African Leafy Vegetables that are grown and consumed in Luhya, Luo and Kisii communities, respectively. In each of the communities, respondents mentioned at least ten African Leafy Vegetables that were grown although the degree and intensity of cultivation varied with the community. The number of African leafy vegetable species grown and used by all $(100 \%)$ respondents was six (6), nine (9) and one (1) for the Luhya, Luo and Kisii communities, respectively (table 1, 2 and 3).

In some cases the same local name was used for the different species but of the same genus. Spiderplant (Cleome gynandra) was the only vegetable that was grown by all the respondents from the three communities as shown in table 4 . Table 4 also shows that the top ten (ten) priority African Leafy Vegetables in the three communities studied were: Cleome gynandra, Solanum villosum, Cucurbita moschata, Vigna unguiculata, Amaranthus blitum, Corchorus olitorius, Solanum scabrum, Crotalaria ochroleuca Crotalaria brevidens and Brassica carinata representing seven botanic

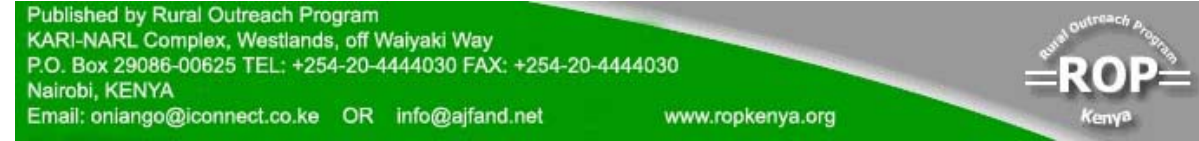




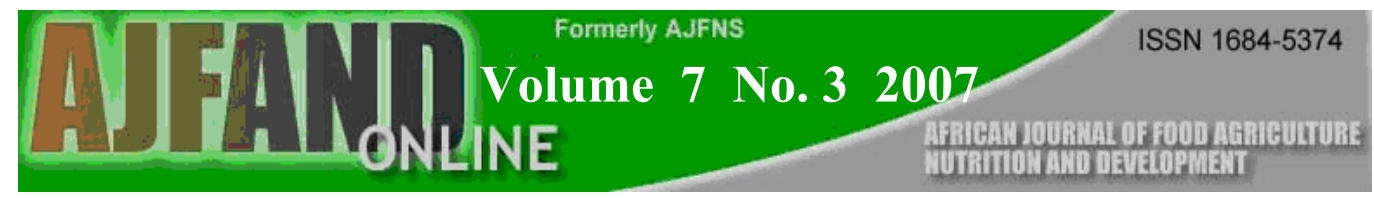

families Amaranthaceae, Brassicaceae, Capparaceae, Cucurbitaceae, Fabaceae, Solanaceae and Tiliaceae.

Luhya and Luo communities had nine (9) African Leafy Vegetables that were grown by $90 \%$ or more of the respondents while the Kisii community had only two (2) in that category.

When asked to name any African Leafy Vegetable that was consumed in the past but is no longer in use, no respondent enlisted such a vegetable in Kisii district. In the Luhya community $25 \%$ of the respondents listed four lost or rare African Leafy Vegetables as "indelema" (Basella alba), "linyolonyolo" (Commelina africana), "Esirietso" (Erythrococa atroviriens) and "Esitipa" (Asytasia mysorensis). Four lost or rare African Leafy Vegetables in the Luo community were identified by $20 \%$ of the respondents as "Atipa" (Asytasia mysorensis), "Achak" (Launaea cornuta), "Onyulo" (Sesamum calycinum) and "odielo" (Commelina africana). When asked to name the African Leafy Vegetable that the respondent prefered, in Kisii community $65 \%$ of the respondents named spiderplant (Cleome gynandra) and 35\% African nightshade(Solanum villosum), in the Luhya community the preferred African Leafy Vegetables were Spiderplant (Cleome gynandra-30\%), Cowpeas (Vigna unguiculata$30 \%$ ), slenderleaf(Crotalaria brevidens/ochroleuca -30\%) African nightshades (Solanum scabrum-5\%) and jute mallow (Corchorus olitorius-5\%), while in the Luo community enlisted cowpeas (Vigna unguiculata-35\%), spiderplant (Cleome gynandra 30\%), slenderleaf (Crotalaria brevidens/ochroleuca -25\%) and jute mallow (Corchorus olitorius) and African nightshades (Solanum scabrum) (each 5\%)

\section{Indigenous knowledge on production, agronomic and cultural practices of African Leafy Vegetables in western Kenya}

In Luhya, Luo and Kisii communities, women made up $80 \%, 95 \%$ and $50 \%$ of the respondents. Land parcels owned by farmers varied from 0.5-5 hectares, 1.5-10 hectares and $0.5-5$ hectares for the Luhya, Luo and Kisii communities respectively and the percentage of land allocated to African Leafy Vegetables varied from 5-30\%. The Kisii community had $20 \%$ of the respondents allocating $25 \%$ or more of land to growing African Leafy Vegetables.

All the respondents stated that they were growing the vegetables for both consumption and for sale. Over $90 \%$ of the interviewed farmers in all the communities studied observed that there had been an increase in the cultivation of African Leafy Vegetables as a result of an increased demand and awareness campaigns. Although, the increase in demand was noted all the respondents were growing the vegetables in home gardens for ease of management and these were grown as intercrops with cereals, legumes, root crops and in certain cases Fruit trees. The crops with which the African Leafy Vegetables were intercropped included maize, millet, sweet potatoes, kale, beans, avocado, cassava, groundnuts or bananas.

Land preparation, planting and weeding were effected using hand hoes and pangas. Planting was done by drilling in rows or broadcasting and thinning after 4-5 weeks. In

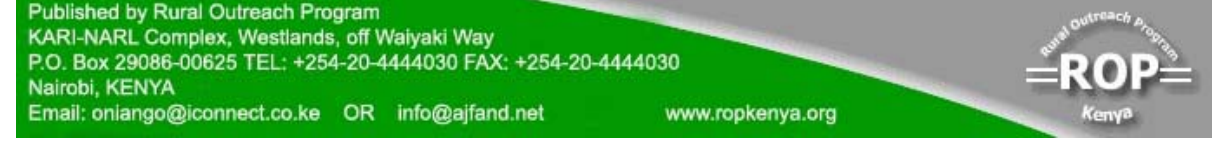


Luhya, Luo and Kisii communities $20 \%, 40 \%$ and $60 \%$ respectively broadcasted the seeds during planting. All the respondents in all the three communities used farm yard manure as a source of macro and micro nutrients and used wood ash to control pests. It was only in the Luo and Kisii communities where one respondent in each case was using Diammonium Phosphate and Urea, respectively.

The planting was done twice a year in all the six districts during the long rains (March-July) and the short rains (September-December). Harvesting was reported to start 4-5 weeks after sowing, at thinning time and thereafter harvesting was done weekly by removal of young shoots resulting in subsequent ratoon crop. This type of harvesting could go on for a period of three months, then another 2 months for seed maturity. Most of the farmers depended on rainfall and only $20 \%$ of farmers from the Luo community practiced irrigation using watering cans.

\section{Major constraints facing production of African Leafy Vegetables western Kenya}

The major constraints identified by respondents from the three communities included:

* Poor seed quality

* Pests and diseases

+ Drought

* Poor marketing channels

* Transport to markers

* Lack of agronomic and utilization packages

\section{DISCUSSION}

\section{Diversity of African Leafy Vegetables in three commmuties in western Kenya}

Ten African leafy vegetable species were found to be cultivated in the three communities in western Kenya and these included Cleome gynandra, Solanum villosum, Cucurbita moschata, Vigna unguiculata, Amaranthus blitum, Corchorus olitorius, Solanum scabrum, Crotalaria ochroleuca Crotalaria brevidens and Brassica carinata representing seven botanic families Amaranthaceae, Brassicaceae, Capparaceae, Cucurbitaceae, Fabaceae, Solanaceae and Tiliaceae. This finding is in line with the market survey report which indicated that, the top eight African Leafy Vegetables in western Kenya were Cleome gynandra, Solanum villosum, Cucurbita moschata, Vigna unguiculata, Amaranthus blitum, Corchorus olitorius, Crotalaria ochroleuc and Brassica carinata. [10, 16].

Results from an earlier study in Kisii indicated that Cleome gynandra and Solanum villosum were the two African Leafy Vegetables with prominence followed by Cucurbita carinata and Vigna unguiculata which agrees with the findings of this study as the first four African Leafy Vegetables of importance in Kisii, although not in the same order [18].

Luhyas, Luos and Kisiis have been reported to have an extra-ordinarily high number of species used as vegetables, an indication of food production systems that evolved

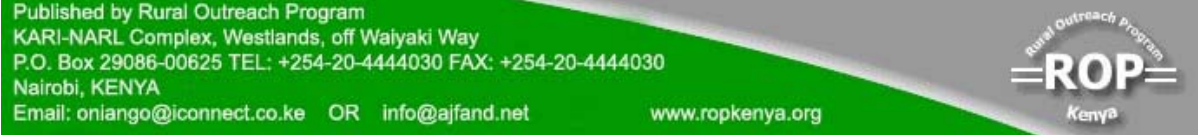


with emphasis on vegetable cooking [7]. Different communities display a combination of economic pursuits but one of them will be prominent and these pursuits include crop farming, pastoralism and hunting/gathering/fishing.

Luhyas, Luos and Kisiis have been placed on agricultural and mixed farming economic system with medium to low dependence on wild plants and animals and this explains why there is a high diversity in African Leafy Vegetables [7]. The lost or rare species of the African indigenous vegetables in the Luhya and Luo communities included Basella alba, Commelina Africana, Erythrococa atroviriens, Asytasia mysorensis, Launaea cornuta and Sesamum calycinum .

These are mainly species which were normally collected from the wild during periods of scarcity without any formal cultivation or occurred as weeds in cereal crops and taken advantage of $[4,18]$. Basella alba was normally found in valleys where there were water sources or streams and small rivers and since it is a perennial vine and has played a vital role in food and nutrition security particularly during the dry periods [19].

As for the preferred African Leafy Vegetables in the three communities, spiderplant, African nightshade, cowpeas, slenderleaf, and jute mallow, the respondents argued that these vegetables were nutritious and made them strong. Spiderplant, African nightshades and slenderleaf were said to have medicinal properties and could heal ailments relating to the stomach. These African Leafy Vegetables that have medicinal attributes are usually sour or bitter and have been reported to contain secondary metabolites like the alkaloids, oxalates and other phenolic compounds that could be responsible for not only the bitterness but also the healing properties $[10,12]$

\section{Indigenous knowledge on production, agronomic and cultural practices of African Leafy Vegetables in western Kenya}

African Leafy Vegetables were reportedly grown mainly in home gardens mostly within the homestead. These are areas where the management practices are easier and the use of farm yard manure is facilitated [5]. Although in this study all the farmers indicated that they grow their African Leafy Vegetables in home gardens, the hardy species like cowpeas and slenderleaf could be grown in main cropping lands as intercrops as they have been shown to do well with nutrient poor soils and with less water [20]. Another reason why farmers grow African Leafy Vegetables in homesteads is for protection from animals and thieves $[4,18]$

Intercropping as a farming system is where two or more crop species are grown on the same piece of land [21]. Intercropping has several advantages that include having diversity of crops in a given season, optimal utilization of resources like nutrients, water and light especially if the intercrops have different growth patterns [22, 23]. Intercrops can be planted with crops that have different maturity dates. Farmers in the three communities have indigenous knowledge that agrees with the established fact that intercropping is advantageous.

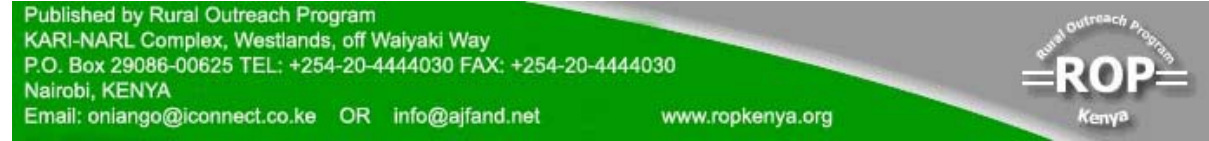


However, in order to assess the benefits of intercropping, Land Equivalent Ratio (LER) for any pair of intercrops must be established. Land Equivalent Ratio compares the yields from an intercrop with that from monocrop at the same level of management [22] and is calculated as follows LER=(Intercrop1/monocrop1) + (intercrop2/monocrop2) if the LER $>1$ then the intercropping of the crops in question is suitable. Some work on intercropping African Leafy Vegetables with cereals has been reported, LER of intercrop of slenderleaf (Crotalaria brevidens) and finger millet (Eleusine coracana) was greater than one, indicating that they are suitable intercrops other suitable intercrops reported include spiderplant (Cleome gynandra) with Maize(Zea mays) and African nightshade (Solanum villosum) with Maize (Zea mays) [17].

It is amazing that all the farmers that were involved in the study were using organic manure as a source of nutrients and wood ash to control pests. The current global trend is to encourage the use of environmentally friendly farming methods by avoiding the use of chemicals that are harmful not only to the environment but also to the consumers. The use of organic sources of manure like farmyard manure and wild sunflower (Tithonia diversifolia) leaves for growing African Leafy Vegetables found in western Kenya has proven useful $[17,24]$. Organic sources of manure, besides providing nutrients to the crop plants, also improve the structure of the soil and give residual effects on subsequent crops [25]

\section{Major constraints facing production of African Leafy Vegetables western Kenya}

Poor seed quality, pests and diseases, drought, poor marketing channels, transport to markets, lack of agronomic and utilization packages are among the major constraints that hinder optimal production of African Leafy Vegetables. In addition to the above, Schippers lists perishability, neglect and lack of awareness of the merits of African Leafy Vegetables [10].

Seed quality is normally affected by the agronomic practices used, the time of harvest and seed processing procedures. Seeds of spiderplant, African nightshades and jute mallow have been reported to have poor germination compared to those of cowpea and slenderleaf due to dormancy characteristics $[10,20]$. Seeds of most African Leafy Vegetables are processed through the dry method while African nightshades seed is normally done by wet processing methods [26].

Proper processing especially of the wet processed seeds is required to ensure complete removal of the flesh pulp that normally contains growth inhibitors. In an endevour to promote sustainable production of African Leafy Vegetables the above constraints have to be addressed holistically but quality seed is key to a successful promotion programme

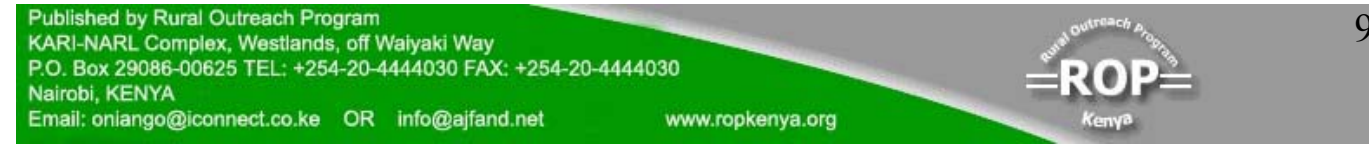




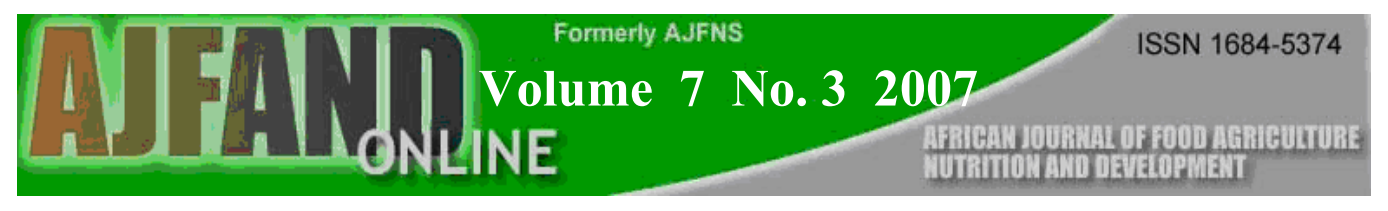

\section{CONCLUSIONS}

The study showed that all the three communities studied had a high diversity of cultivated African Leafy Vegetables covering eight botanic families

\& Respondents in all the communities cultivate African Leafy Vegetables in subsistence, home gardening, intercrop systems where the use of chemical fertilizers and chemicals was almost non-existent.

+ The major constraints of production of African Leafy Vegetables included poor quality seed, drought, poor marketing systems and infrastructure and lack of agronomic and utilization packages

* The identified African Leafy Vegetables in western Kenya which should be promoted and improved as commercial crops included spiderplant, African nightshade, pumpkin leaves, cowpeas, vegetable amaranths, jute mallow, slenderleaf and African kale.

\section{ACKNOWLEDGEMENT}

The author is grateful to IPGRI African Leafy Vegetables Programme for funding the study and Maseno University for the providing the facilities and giving logistical and institutional support, Patrick Omulubi, Peter Olewe and Joseph Nyanchoka Ndemo for assisting me in the administration of the questionnaires in different the three communities. 


\section{TABLES}

Table 1: African Leafy Vegetables found in Vihiga and Butere/Mumias Districts (Luhya Community)

\begin{tabular}{|l|l|l|l|l|l|}
\hline No & $\begin{array}{l}\text { Luhya } \\
\text { name }\end{array}$ & Swahili name & Common English name & Scientific name & $\%$ \\
\hline $\mathbf{1}$ & Tsisaka & Mgagani & Spiderplant & Cleome gynandra & 100 \\
\hline $\mathbf{2}$ & Likhubi & Kunde & Cowpeas & Vigna unguiculata & 100 \\
\hline $\mathbf{3}$ & Lisutsa & Mnavu & African nightshade & Solanum villosum & 100 \\
\hline $\mathbf{4}$ & Emiro & Marejea & Slenderleaf & Crotalaria ochroleuca & 100 \\
\hline $\mathbf{5}$ & Omurere & mlenda & Jute mallow & Corchorus olitorius & 100 \\
\hline $\mathbf{6}$ & Lisebebe & Malenge & Pumpkin leaves & Cucurbita moschata & 100 \\
\hline $\mathbf{7}$ & Lisutsa & Mnavu & African nightshade & Solanum scabrum & 90 \\
\hline $\mathbf{8}$ & Libokoi & Mchicha & Vegetable amaranths & Amaranthus blitum & 90 \\
\hline $\mathbf{9}$ & Emiro & Marejea & Slenderleaf & Crotalaria brevidens & 90 \\
\hline $\mathbf{1 0}$ & Kanzira & - & African kale & Brassica carinata & 50 \\
\hline $\mathbf{1 1}$ & Indelema & - & Vine spinach & Basella alba & 03 \\
\hline
\end{tabular}

Table 2: African Leafy Vegetables found in Kisumu and Siaya Districts (Luo Community)

\begin{tabular}{|l|l|l|l|l|l|}
\hline No & Luo name & $\begin{array}{l}\text { Swahili } \\
\text { name }\end{array}$ & Common English name & Scientific name & $\mathbf{\%}$ \\
\hline $\mathbf{1}$ & Dek & Mgagani & Spiderplant & Cleome gynandra & 100 \\
\hline $\mathbf{2}$ & A lot-boo & Kunde & Cowpeas & Vigna unguiculata & 100 \\
\hline $\mathbf{3}$ & Ododo & Mchicha & Vegetable amaranths & Amaranthus blitum & 100 \\
\hline $\mathbf{4}$ & Osuga & Mnavu & African nightshade & Solanum scabrum & 100 \\
\hline $\mathbf{5}$ & Osuga & Mnavu & African nightshade & Solanum villosum & 100 \\
\hline $\mathbf{6}$ & Mitoo & Marejea & Slenderleaf & Crotalaria brevidens & 100 \\
\hline $\mathbf{7}$ & Mitoo & Marejea & Slenderleaf & Crotalaria ochroleuca & 100 \\
\hline $\mathbf{8}$ & Apoth & mlenda & Jute mallow & Corchorus olitorius & 100 \\
\hline $\mathbf{9}$ & Budho & Malenge & Pumpkin leaves & Cucurbita moschata & 100 \\
\hline $\mathbf{1 1}$ & Kadhira & - & African kale & Brassica carinata & 60 \\
\hline
\end{tabular}

Table 3: African Leafy Vegetables found in Kisii and Nyamira Districts

(Kisii Community)

\begin{tabular}{|l|l|l|l|l|l|}
\hline No & Kisii name & Swahili name & Common English name & Scientific name & $\mathbf{\%}$ \\
\hline $\mathbf{1}$ & Chinsaga & Mgagani & Spiderplant & Cleome gynandra & 100 \\
\hline $\mathbf{2}$ & Rinagu & Mnavu & African nightshade & Solanum villosum & 90 \\
\hline $\mathbf{3}$ & Omuongo & Malenge & Pumpkin leaves & Cucurbita moschata & 45 \\
\hline $\mathbf{4}$ & Egesare & Kunde & Cowpeas & Vigna unguiculata & 40 \\
\hline $\mathbf{5}$ & Emboga & Mchicha & Vegetable amaranths & Amaranthus blitum & 40 \\
\hline $\mathbf{6}$ & Rinagu & Mnavu & African nightshade & Solanum scabrum & 30 \\
\hline $\mathbf{7}$ & Omotere & mlenda & Jute mallow & Corchorus olitorius & 25 \\
\hline $\mathbf{8}$ & Enderema & - & Vine spinach & Basella alba & 06 \\
\hline $\mathbf{9}$ & Mitoo & Marejea & Slenderleaf & $\begin{array}{l}\text { Crotalaria } \\
\text { ochroleuca }\end{array}$ & 06 \\
\hline $\mathbf{1 0}$ & - & Sukuma ya kiasili & African kale & Brassica carinata & 00 \\
\hline
\end{tabular}

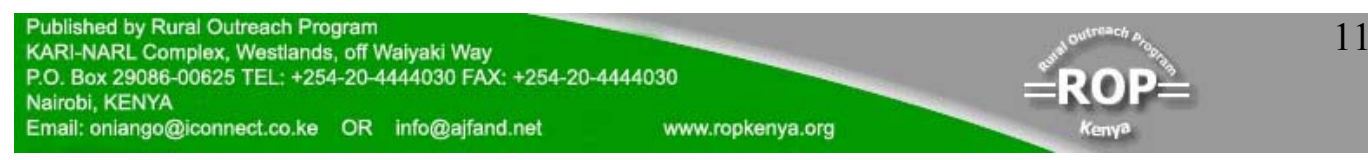


Table 4: Ten priority African Leafy Vegetables in Luhya, Luo And Kisii communities in western Kenya

\begin{tabular}{|l|l|l|l|l|l|l|}
\hline No & $\begin{array}{l}\text { African } \\
\text { Vegetable }\end{array}$ & Beafy & Luhya & Luo & Kisii's & Total \\
\hline $\mathbf{1}$ & Spiderplant & Capparaceae & 100 & 100 & 100 & 300 \\
\hline $\mathbf{2}$ & $\begin{array}{l}\text { African nightshade } \\
\text { (S.villosum) }\end{array}$ & Solanaceae & 100 & 100 & 090 & 290 \\
\hline $\mathbf{3}$ & Pumpkin leaves & Cucurbitaceae & 100 & 100 & 045 & 245 \\
\hline $\mathbf{4}$ & Cowpeas & Fabaceae & 100 & 100 & 040 & 240 \\
\hline $\mathbf{5}$ & Vegetable Amaranths & Amaranthaceae & 090 & 100 & 040 & 230 \\
\hline $\mathbf{7}$ & Jute mallow & Tiliaceae & 100 & 100 & 025 & 225 \\
\hline & $\begin{array}{l}\text { African nightshade } \\
(\text { S.scabrum })\end{array}$ & Solanaceae & 090 & 100 & 030 & 220 \\
\hline $\mathbf{8}$ & $\begin{array}{l}\text { Slenderleaf } \\
(\text { C.ochroleuca })\end{array}$ & Fabaceae & 100 & 100 & 006 & 206 \\
\hline $\mathbf{9}$ & $\begin{array}{l}\text { Slenderleaf } \\
(\text { C.brevidens })\end{array}$ & Fabaceae & 090 & 100 & 000 & 190 \\
\hline $\mathbf{1 0}$ & African kale & Brassicaceae & 050 & 060 & 000 & 110 \\
\hline
\end{tabular}

Table 5: Land allocated to African Leafy Vegetables in three communities in western Kenya

\begin{tabular}{|l|l|l|l|l|}
\hline \multirow{2}{*}{ No } & \multirow{2}{*}{ \%Land under } & \% of interviewed farmers & \\
\cline { 3 - 5 } & ALVs & Luhya & Luo & Kisii \\
\hline 1. & 30 & - & - & 10 \\
\hline 2. & 25 & - & - & 10 \\
\hline 3. & 20 & 10 & - & 25 \\
\hline 4. & 15 & 25 & 40 & 25 \\
\hline 5. & 10 & 45 & 30 & 18 \\
\hline 6. & 5 & 20 & 30 & 12 \\
\hline \multicolumn{2}{|l|}{ TOTAL } & $\mathbf{1 0 0}$ & $\mathbf{1 0 0}$ & $\mathbf{1 0 0}$ \\
\hline
\end{tabular}




\section{REFERENCES}

1. AICAD Examination of the needs through the study of poverty reduction strategy papers for Kenya, Uganda and Tanzania. African Institute for capacity Development and Japan International cooperation Agency. 2003: 1-54.

2. GoK National poverty eradication plan 1999-2015. Department of development co-ordination, 1999.

3. GoK National home-based care programme and service guidelines. National AIDS/STD Control Programme. Ministry of Health, 2002.

4. Maundu PM, Ngugi GW and CH Kabuye Traditional Food plants of Kenya. KENRIK, National museums of Kenya, 1999: 270.

5. Chweya JA and PB Eyzaguire (eds) The biodiversity of traditional Leafy Vegetables. International Plant Genetic Resources Institute, Rome, Italy, 1999.

6. Maundu PM The status of traditional vegetable utilization in Kenya. In: L Guarino (Ed). Proceedings of the IPGRI International workshop on genetic resources of traditional vegetables in Africa: Conservation and use. ICRAFHQ, Nairobi, Kenya 1997:66-75.

7. Grubben GJH and OA Denton. (Eds) Plant Resources of Tropical Africa 2.Vegetables. PROTA Foundation, Wageningen, Netherlands/Backhuys Publishers, Leiden, Netherlands/CTA, Wageningen, Netherlands. 2004.

8. Olembo NK, Fedha SS and ES Ngaira 1995 Medicinal and Agricultural Plants of Ikolomani, Kakamega District.1995.

9. Schippers RR African indigenous vegetables an overview of the cultivated species. Chatham, UK. Natural Resources Institute /ACP-EU Technical Centre for Agricultural and rural Cooperation.2002.

10. Mnzava NA Vegetable crop diversification and the place of traditional species in the tropics. In: L Guarino (Ed). Proceedings of the IPGRI International workshop on genetic resources of traditional vegetables in Africa: Conservation and use. ICRAF-HQ, Nairobi, Kenya 1997:1-15.

11. Abukutsa-Onyango MO Unexploited potential of indigenous African indigenous vegetables in Western Kenya. Maseno Journal of Education, Arts and Science 2003; 4:103-122.

12. Chweya JA Identification and nutritional importance of indigenous green leaf vegetables in Kenya. Acta Hort. 1985; 153:99-108. 
13. Kokwaro JO Medicinal plants of East Africa. East African Literature Bureau. Kampala, Nairobi, Dar es Salaam, 1976.

14. Abukutsa-Onyango MO Crotalaria brevidens Benth. In: GJH Grubben, \& Denton, OA (Eds). Plant Resources of Tropical Africa 2.Vegetables. PROTA Foundation, Wageningen, Netherlands/Backhuys Publishers, Leiden, Netherlands/CTA, Wageningen, Netherlands 2004:229-231.

15. Abukutsa-Onyango MO Market survey on African indigenous vegetables in Western Kenya. In: JM Wesonga T Losenge CK Ndung'u K.Ngamau JBM Njoroge, FK Ombwara, SG Agong, A Fricke, B Hau and H Stutzel (Eds) Proceedings of the second Horticulture seminar on Sustainable Horticultural production in the tropics. JKUAT 2002: 39-46.

16. Chweya JA Genetic enhancement of indigenous vegetables in Kenya. In: L Guarino (Ed). Proceedings of the IPGRI International workshop on genetic resources of traditional vegetables in Africa: Conservation and use. ICRAFHQ, Nairobi, Kenya 1997:86-95.

17. Maundu PM, Njiro ES, Chweya JA, Imungi JK and EN Seme Kenya In: JA Chweya and PB Eyzaguire (Eds) The biodiversity of traditional Leafy Vegetables. International Plant Genetic Resources Institute, Rome, Italy, 1999: 51-84.

18. Abukutsa-Onyango MO Crotalaria brevidens Benth. In: GJH Grubben \& OA Denton,. (Eds). Plant Resources of Tropical Africa 2.Vegetables. PROTA Foundation, Wageningen, Netherlands/Backhuys Publishers, Leiden, Netherlands/CTA, Wageningen, Netherlands 2004:229-231.

19. Abukutsa-Onyango MO Effect of nitrogen rates on germination of stored seed of slenderleaf (Crotalaria brevidens) In: JM Wesonga (Eds) Proceedings of the fourth workshop on Sustainable Horticultural production in the tropics. Moi University, Eldoret 2005:188-195.

20. Willey RW Intercropping: Its importance and research need part 1 . Competition and yield advantages. Field crop abstracts Commonwealth bureau of pastures and field crops 1979; 32:1-10.

21. Baumann DT, Kropff MJ and L Bastiaans Intercropping leeks to suppress weeds. Weed Res 2002; 40:359-374.

22. Liebman $\mathbf{M}$ and $\mathbf{E}$ Dyck Crop rotation and intercropping strategies for weed management. Ecological applications 1993;3:92-122.

23. Onyango MOA, Onyango JC, Bashir J, Niang A and HM Obiero Response of some traditional vegetables in Western Kenya to organic fertilizer application. In: MOA Onyango JC Onyango and B Jama (Eds). Traditional 


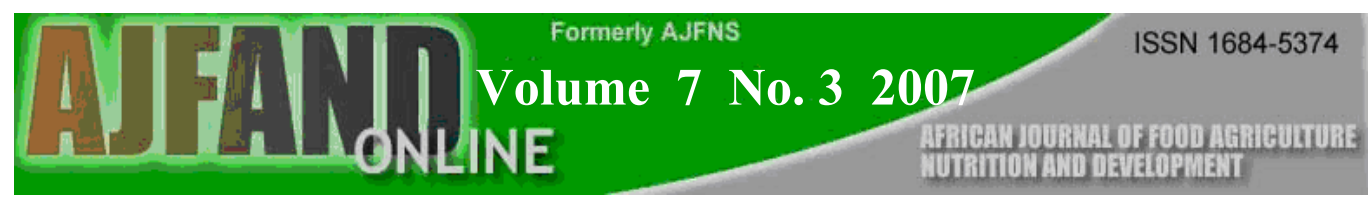

crops in western Kenya: Adaptive Technologies for increased production. IRPS Maseno University 1999 Reprint series no 3:1-13.

24. Marschner H Mineral Nutrition of Higher Plants. Second Edition. Academic Press, 1995.

25. AVRDC Vegetable production training manual. Asian vegetable research and development centre. Shahnua, Tainan 1992. 